\title{
Degradation of Mutant Proteins, Underlying "Loss of Function" Phenotypes, Plays a Major Role in Genetic Disease
}

\author{
Paula J. Waters* \\ Department of Human Genetics, PT-413, \\ McGill University-Montreal Children's Hospital Research \\ Institute, 4060 Saint Catherine St. West, Westmount, \\ Quebec, Canada, H3Z 2 Z3
}

\begin{abstract}
Many Mendelian monogenic disorders are caused by loss of the function of a single protein. This can result from rapid degradation of the mutant protein by cellular proteases, which reduces the steady-state concentration of the protein within the cell. The susceptibility of a protein to such proteolytic breakdown depends upon its kinetics of monomer folding and oligomer assembly and upon the intrinsic (thermodynamic) stability of its functional native-state conformation. Other cellular proteins, notably molecular chaperones, promote correct protein folding and assembly and thus provide some protection against degradation. An accumulation of recent evidence indicates that premature or accelerated degradation of mutant proteins, provoked by aberrations in their conformation, occurs in various subcellular compartments and represents a significant and prevalent pathogenic mechanism underlying genetic diseases. Inter-individual variability in proteolytic and folding systems can in part explain why "simple monogenic diseases" often display inconsistent genotype-phenotype correlations which show these disorders to be in reality quite complex. Protein folding and degradation may also be modulated artificially using exogenous small molecules. The identification or design of compounds which can interact specifically with particular target proteins, and which in so doing can exert beneficial effects on protein folding, assembly and/or stability, is beginning to open up a new and remarkably promising avenue for the treatment of diverse genetic disorders.
\end{abstract}

\section{Introduction}

The majority of currently known monogenic diseases reflect a "loss of function" phenotype. In these diseases mutation at the specific gene locus results directly in the absence or

*For correspondence. Email paula.waters@muhc.mcgill.ca; Tel. (514)-412-4400 X 2953/2761; Fax. (514)-412-4478. reduction of some essential cellular function for which the encoded protein (such as an enzyme, hormone, receptor, transporter or channel) is responsible. Such disorders are generally inherited in a recessive fashion, since the presence of a single wild-type allele in a heterozygous individual will usually suffice to produce an adequate supply of normal functional protein (Hartman et al., 2001). The reason for the deleterious impact of some diseaseassociated mutations is obvious; for major deletions, insertions, rearrangements or RNA splicing changes, and for most nonsense and frameshift mutations, it is evident that they will preclude the synthesis of a functional protein. However, of the over 21,000 mutations currently recorded in the Human Gene Mutation Database (http:// www.uwcm.ac.uk/uwcm/mg/hgmdO.html; Krawczak et al., 2000), half are missense mutations, causing substitution of a single amino acid residue, while many others represent only small inframe deletions or insertions. It is increasingly apparent that very few of these mutations alter amino acid residues in catalytic sites, ligand binding sites or other locations critical for function. This then has highlighted the question of how such mutations cause loss of protein function: if they do not substantially affect the specific activity of the protein molecule, could they instead exert their disease-causing effects by reducing the cellular levels of the active protein?

The steady-state concentration of a protein within the cell is determined by the dynamic balance between its synthesis and degradation. The concept that missense mutations might accelerate the degradation of a protein is not new; in fact initial experimental support for this idea predates the era of molecular biology (Capecchi et al., 1974). However it is only quite recently that there has been a renaissance among human geneticists of interest in protein degradation as a potential disease-causing mechanism. This has been fuelled by the clear demonstration that protein degradation is an essential part of diverse physiological processes and by the accompanying surge in basic research identifying and characterising proteolytic systems in all compartments of the cell (Mayer, 2000).

Understanding of proteolytic processes within cells is incomplete without an awareness of the cellular systems, such as molecular chaperones, which can regulate protein folding and assembly. These systems are intimately entwined with degradative pathways, in networks together referred to as the cell's "protein quality control" system (Ellgard et al., 1999; Wickner et al., 1999). Again basic scientists have been laying a thorough groundwork in this area, on which those studying human genetic disease now have the opportunity to capitalise. 


\begin{tabular}{|c|c|c|c|c|}
\hline Protein & Disease associated with mutations & Normal site of function & $\begin{array}{l}\text { Site of degradation } \\
\text { of mutant form }\end{array}$ & Reference \\
\hline Aquaporin 2 & Nephrogenic diabetes insipidus & Plasma membrane & $\begin{array}{l}\text { Endoplasmic } \\
\text { reticulum }(E R)^{a}\end{array}$ & Tamarappoo and Verkman, 1998 \\
\hline Insulin proreceptor & Diabetes mellitus & Plasma membrane & $\mathrm{ER}^{\mathrm{a}}$ & Bass et al., 2000 \\
\hline PHEX & X-linked hypophosphatemia & Plasma membrane & $\mathrm{ER}^{\mathrm{a}}$ & \\
\hline $\begin{array}{l}\mathrm{N} \text {-acetylgalactosamine- } \\
\text { 4-sulphatase }\end{array}$ & $\begin{array}{l}\text { Mucopolysaccharidosis VI } \\
\text { (Maroteaux-Lamy) }\end{array}$ & Lysosomes & $\mathrm{ER}^{\mathrm{a}}$ & Bradford et al., 1999 \\
\hline Sialidase (neuraminidase) & Sialidosis & Lysosomes & Lysosomes & Lukong et al., 2001 \\
\hline $\begin{array}{l}\text { Short-chain acyl-coA } \\
\text { dehydrogenase }\end{array}$ & $\begin{array}{l}\text { Short-chain fatty acid oxidation } \\
\text { deficiency }\end{array}$ & Mitochondria & Mitochondria & Corydon et al., 1998 \\
\hline Phenylalanine hydroxylase & Phenylketonuria & Cytosol & Not known ${ }^{c}$ & Waters et al., 2000 \\
\hline Galactose-1-phosphate & Galactosemia & Cytosol & Not known ${ }^{c}$ & Lai et al., 1998 \\
\hline
\end{tabular}

uridyltransferase

In all of these cases mutations have been rigorously shown, by pulse-chase analysis, to cause accelerated or premature degradation of the protein.

a "ER degradation" refers to degradation initiated in the ER; it can involve proteasomal degradation following retrotranslocation to the cytosol and/or proteolysis by enzymes within the ER itself (reviewed by Bross et al., 1999; Kopito and Sitia, 2000).

b Y. Sabbagh and H.S. Tenenhouse, personal communication.

${ }^{c}$ These proteins are synthesised in the cytosol, which is also their normal site of action; therefore it is reasonable to suppose that their degradation is initiated in the cytosol.

An overview of the field as it stood in 1999 (Bross et al., 1999; Gregersen et al., 2000) concluded that enhanced proteolytic degradation of mutant proteins, resulting from their impaired folding, is a common pathological mechanism in genetic disease; despite the fact that such a mechanism had been "rigorously proven in only a handful of examples" (Bross et al., 1999). The present article examines recent data on protein degradation in "loss of function" phenotypes, and shows an ongoing accumulation of evidence for the far-reaching significance of this theme. Three main areas are briefly discussed: the implication of protein degradation in the pathogenesis of a growing catalogue of genetic disorders; the potential for interindividual variability in protein degradation to modulate phenotype in monogenic diseases; and promising new approaches to therapeutic intervention.

\section{Evidence for Accelerated Degradation of Mutant Proteins}

Any excursion into the literature on mutations in inherited metabolic disorders rapidly uncovers numerous instances where mutant proteins are shown, by immunoblotting of extracts from patient-derived cells or of transfected mammalian cells, to be expressed at lower levels than their wild-type counterparts. This is often ascribed, rather imprecisely, to "protein instability" and/or assumed to represent "degradation". Such observations are not in themselves conclusive of accelerated protein turnover, particularly in the absence of a demonstration that messenger RNA production and protein synthesis are proceeding normally. Nonetheless, the sheer mass of this type of data at least suggests, and compels one to consider, the hypothesis that rapid degradation of mutant proteins could be a prevalent disease-causing mechanism.

A second line of indirect support for this hypothesis has been supplied by evidence of impeded cellular trafficking of some mutant proteins. Localisation studies, by subcellular fractionation or immunostaining of cells, have often indicated that mutant isoforms fail to reach the protein's normal destination. Observations of incomplete post-translational processing, revealed by immature patterns of modifications such as glycosylation, also imply a block in trafficking. Numerous examples of such findings (reviewed by Brooks, 1997; Kuznetsov and Nigam, 1998) have suggested that many diverse mutant proteins are unable to progress beyond the endoplasmic reticulum (ER) to their correct sites of action, which may be in other organelles, in the plasma membrane, or outside the cell following secretion. When there is no sign of abnormal accumulation of the mutant protein within the cell then it is often presumed, quite reasonably, to be prematurely degraded at the ER stage; as was shown to be the case for the prototype example, the $\Delta \mathrm{F} 508$ mutant form of the cystic fibrosis transmembrane conductance regulator (CFTR) (Ward and Kopito, 1994).

Direct evidence for the rapid degradation of a number of mutant proteins has been provided by metabolic labelling experiments. In the classical "pulse-chase" technique, which is the "gold standard" for investigations into protein turnover, a radiolabelled amino acid is added to cells or cell extracts, and is incorporated into newly-synthesised protein. This incorporation is terminated by the addition of excess unlabelled amino acid, samples are taken at sequential time points, and the protein of interest quantitated by immunoprecipitation. This approach may be applied to track a protein as it is processed or traverses different subcellular compartments; as well as to measure rates of protein degradation. Table 1 summarises some recently-described examples where this technique, or a variant of it, was used to analyse the fate of mutant proteins containing single amino acid substitutions. In each case mutant proteins were shown to be degraded either prematurely (i.e. prior to reaching the normal site of function within the cell) or at an accelerated rate compared to the wild-type. These examples illustrate the fact that degradation of mutant proteins is certainly not restricted to those which pass through the ER, and show that 


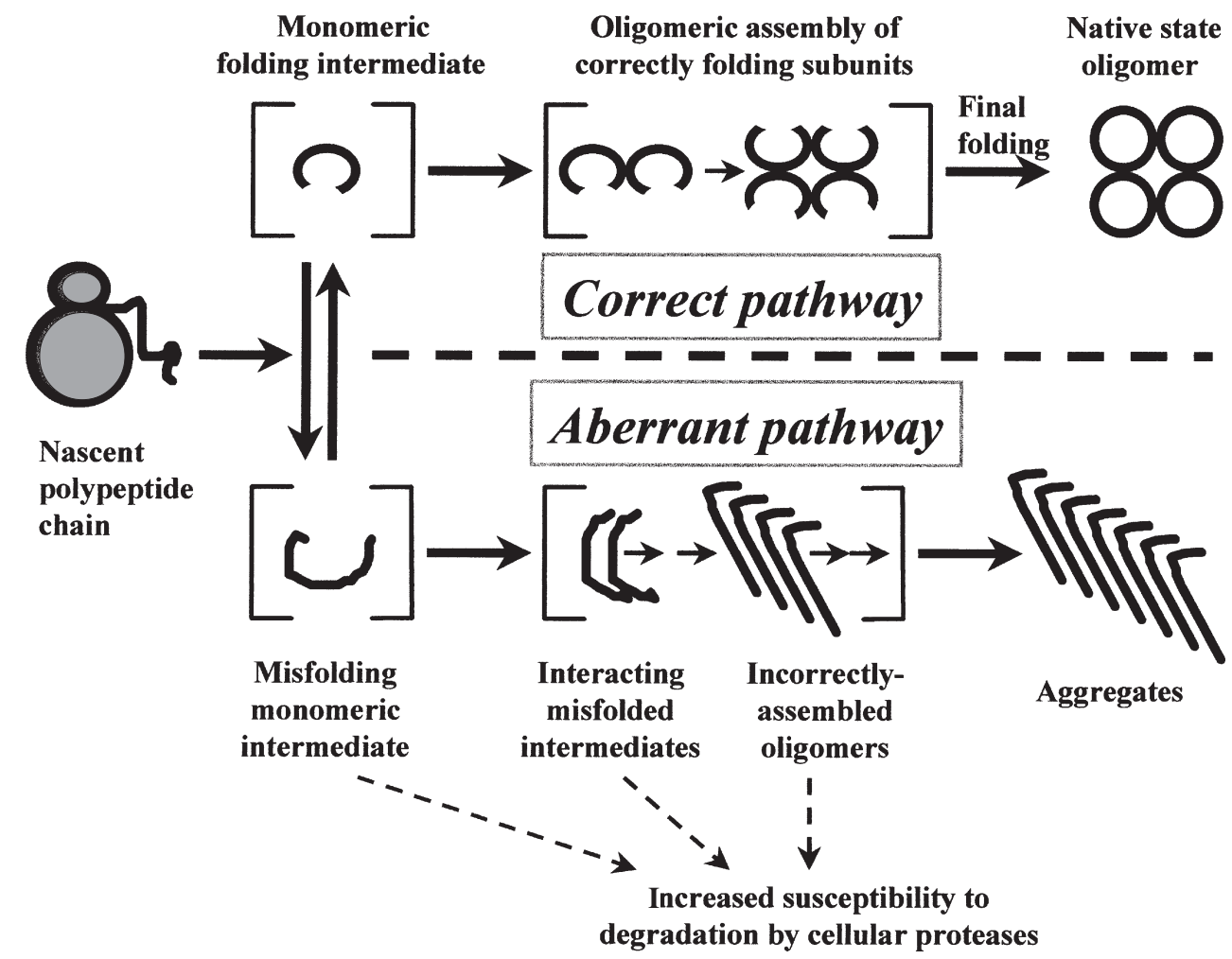

Figure 1. Model of competing pathways for correct versus aberrant protein folding and assembly. (Reprinted, in modified form, from Scriver and Waters 1999 , copyright (1999), with permission from Elsevier Science. Originally adapted from Betts et al., 1997). The monomeric folding intermediate is in equilibrium with one or more misfolding intermediates. Mutation, or environmental factors such as high temperature, can adversely affect rates of correct folding and thus shift this equilibrium towards the misfolding intermediate. This results in a greater proportion of protein entering the aberrant pathway, where it is more susceptible to proteolytic degradation than is protein proceeding through the pathway of correct folding and assembly.

accelerated proteolysis can occur in various subcellular compartments.

Gaps in our understanding of these processes remain; in most cases the particular proteases responsible have not been defined. Elucidation of the factors involved in the degradation of a given mutant protein is facilitated both by the use of cell-permeable, specific protease inhibitors, many of which are now widely available, and by proteasedeficient cell lines (Bass et al., 2000). However, this will often not be a simple task: multiple degradative pathways can act on a single protein (Fayadat et al., 2000); new proteases, which can compensate for impaired function of the currently-known ones, or work in an integrated manner with them, continue to be discovered (Geier et al., 1999; Wang et al., 2000); and inhibition of a single protease can trigger cellular responses involving the activation of other proteolytic pathways (Wagenkrecht et al., 2000). Another challenge arises from the fact that co-translational, rather than post-translational, degradation is probably a major contributor to proteolysis, requiring novel techniques for its detection (Turner and Varshavsky, 2000).

Degradation of mutant proteins has now been strongly implicated in the etiology of a small, but growing, number of genetic disorders. It would seem that when clear evidence for the existence of this phenomenon is actively sought, it is usually found. These observations, when considered together with the more circumstantial evidence so far obtained in a far greater number of disorders, begin to make a convincing case for the importance of proteolysis in the pathogenesis of inherited loss of function phenotypes.

\section{Misfolding and Misassembly are Triggers for Protein Degradation}

Any newly-synthesised protein molecule, whether mutant or wild-type, can enter one of two competing pathway types, shown schematically in Figure 1. It has been shown, initially by in vitro mutagenesis studies on model proteins (Hawkes et al., 1984; Betts et al., 1997) and then by analysis of disease-related mutant proteins (Brown et al., 1997; Bross et al., 1998; Gamez et al., 2000; Waters et al., 2000), that missense mutations can reduce the production of functional protein in one or both of two distinct ways (see Figure 1; also Figure 1B of Bross et al., 1999). First, mutations can decrease the thermodynamic stability (i.e. increase the free energy) of the functional native state conformation. Reasons for destabilisation of this structure may sometimes be apparent when an amino acid substitution is examined in the context of 3D-protein crystal structure. Such reduced stability increases the propensity of the protein to unfold from the native state. Secondly, mutations can decrease the rate of correct folding, affecting the kinetic partitioning of the protein between the competing pathways; so that a smaller proportion of newly-synthesised protein enters and proceeds through the correct pathway for folding and assembly. It is impossible to predict ab initio how a mutation 
will affect folding pathways, since an amino acid may play a pivotal role in some transient intermediate structure but not have an important function in the final native state conformation (Betts et al., 1997; Waters et al., 2000). A huge research effort in the mathematical and physical sciences is now underway, using sophisticated experimental techniques and theoretical approaches to resolve the "protein folding problem" (Baker , 2000; Dinner et al., 2000).

Meanwhile there is much empirical evidence that mutant proteins involved in loss-of-function disease phenotypes display an aberrant protein monomer conformation and/or altered oligomerisation. Studies including the use of conformation-sensitive antibodies, spectroscopic analysis, size exclusion chromatography and non-denaturing gel electrophoresis (Brooks, 1997; Bross et al., 1999; Waters et al., 2000) show conclusively that accelerated degradation of mutant proteins in various subcellular compartments is linked to their aberrant folding or assembly. Proteolytic systems are present in most, probably all, subcellular compartments (Suzuki et al., 1997; Netzer and Hartl, 1998; Bross et al., 1999; Wickner et al., 1999; Leroux and Hartl, 2000). While different proteases are found in different parts of the cell they mostly share a broad substrate specificity, particularly recognising stretches of hydrophobic amino acids which are normally buried in the interior of correctly folded proteins. Studies on structure and mechanism of these proteases shows that some can only act upon unfolded proteins, while others can cleave partially folded proteins. Additional proteases recognise much more specific cleavage-site sequences (Kato et al., 1999), which again may become more exposed due to alterations (ranging from major to very modest) in folding (Bass et al., 2000). Considerable redundancy among proteases renders the overall system highly stringent and it can be sensitive to even very slight differences in protein conformation (Ellgard et al., 1999; Wickner et al., 1999).

The reason why the cell must possess such extremely sensitive and stringent systems for protein degradation is not simply apparent on consideration of the classic loss of function disease phenotypes, in which proteolysis actually leads to disease. However the reason becomes abundantly clear on examination of other disorders in which the cell fails to remove certain aberrant proteins, which apparently evade or swamp the cell's capacity for proteolysis; and then by their continued presence cause catastrophic problems. A large group of dominantly-inherited disorders affecting structural proteins reveal how the aberrant structure of the mutant protein damages the function of the wild-type protein (the "dominant negative" mutant phenotype effect) and usually also of other structural proteins with which it interacts, and in this way greatly perturbs the functional architecture of the cell (Byers, 2001; Dietz and Pyeritz, 2001). Another group of "gain of (abnormal) function" disorders includes neurodegenerative disorders such as Alzheimer's, Parkinson's, Huntington's and Creutzfeld-Jakob diseases, and systemic amyloid protein disorders; as well as acquired disorders involving prion proteins. In all of these conditions the aberrant protein progresses to form aggregates (Figure 1), which are protease-resistant and appear to be highly toxic to the cell (Wickner et al., 1999; Kopito, 2000; Wanker, 2000; Benson, 2001). Loss of function phenotypes may in fact sometimes represent a "better" alternative to a gain of function scenario: for example, PiZZ $\alpha 1$-antitrypsin ( $\alpha 1$-AT) deficiency (Wu et al., 1994) is an example of a loss of function disease in which emphysema results from the absence of circulating $\alpha 1-\mathrm{AT}$, which would normally protect the lungs against damage by neutrophil proteases. In a subset of patients, however, accumulation of some misfolded $\alpha 1-$ ATZ protein in liver causes an additional liver pathology. Overall, then, the cell is required to strike a precarious balance which in most cases results in the "lesser of two evils". But the degradative system is limited in its ability to discriminate between serious alterations in protein conformation and those which could have negligible effects within the cell; and the tremendous cost of this limitation is implied by examples where some mutant proteins, which have extremely subtle folding defects allowing them to remain fully functional, suffer rapid degradation (Tamarappoo et al., 1999).

\section{Cellular Defences Against Protein Misfolding and Misassembly}

Since misfolding and misassembly lead towards the serious consequences of excessive protein degradation or aggregation, cells require strategies to pre-empt these occurrences as far as possible. Protective systems, notably molecular chaperones, are accordingly present in all cell types, and in all organelles (reviewed by Bross et al., 1999; Ellgard et al., 1999; Wickner et al., 1999; Agashe and Hartl, 2000; DeFranco, 2000). While all of the information required for correct folding of a protein resides within its own primary sequence, chaperones can interact transiently with proteins in such a way as to protect them from entering aberrant pathways, thus buying them time to fold properly into their native conformations. Broad-specificity chaperones identify misfolded proteins by the same general biophysical properties which proteases recognise; hydrophobic surface patches in particular, also mobile peptide loops and lack of compactness. Two classes of chaperones act, usually in concert, on newly-synthesised polypeptides; chaperonins physically sequester unfolded proteins in an internal chamber, while "folding helper" chaperones appear to protect nascent chains during translation and to partially unfold misfolding intermediates. Some chaperones of the latter class can also protect or assist during assembly of folded subunits into oligomers (Tyedmers et al., 2000) and even, to a limited degree, solubilise aggregates already formed (Diamant et al., 2000; Kopito and Sitia, 2000; Wickner et al., 2000). There are also other more specialised protective proteins (Ellgard et al., 2000) which appear to interact with only one or a few other proteins; these include chaperones with narrow specificity, "escort proteins" which accompany a protein during its trafficking through the cell, or proteins which are required to stabilise the functional conformation of other proteins throughout their lifetimes by forming a multiprotein complex with them (Lukong et al.; Vinogradova et al., 1998).

Some, but certainly not all, wild-type proteins interact 
in vivo with molecular chaperones. These represent a subset of proteins whose folding and assembly is naturally very inefficient, so that they require additional aid if sufficient protein is to attain the functional native state conformation (Netzer and Hartl, 1998; Wickner et al., 1999; Berson et al., 2000; Fayadat et al., 2000; Leroux and Hartl, 2000). Many mutant proteins show chaperone interactions which in the case of the corresponding wild-type protein either do not occur at all or are far more transient (Brooks, 1997; Kuznetsov and Nigam, 1998; Bross et al., 1999; Bass et al., 2000; Jorgensen et al., 2000). This suggests that these mutant proteins are receiving additional opportunities to fold and assemble correctly. The principle that chaperones may attenuate the loss-of-function phenotype associated with mutant proteins has also been demonstrated by experiments involving the co-overexpression, in transformed bacterial cells, of bacterial chaperones together with mutant human cytosolic or mitochondrial proteins (Castanie et al., 1997; Bross et al., 1998; Gamez et al., 2000). In these studies the additional exogenous chaperones increased the yield of a soluble and active form of the mutant protein.

\section{Protein Folding and Degradation Can Contribute to Complexity in "Single-Gene" Diseases}

Most Mendelian monogenic "loss of function" diseases display inter-individual variability in phenotypic outcome; parameters such as age of onset and severity and range of symptoms can differ enormously between patients. At the beginning of the 1990s, as many disease-associated genes were cloned and the technologies for DNA mutation detection and in vitro protein expression analysis of mutation effects became available, hopes ran high that this phenotypic variability would be largely explicable in terms of allelic heterogeneity at the primary disease gene locus. The widespread expectation was that genotype at that locus would be a simple predictor of phenotype, enabling accurate prognosis and tailoring of treatment. A decade later it is clear that many monogenic disorders are indeed associated with a remarkable degree of allelic heterogeneity, with hundreds of different disease-causing mutations often being recorded for a single locus. However, it is also evident that genotype does not always consistently predict phenotype; in vitro analysis and population-based studies may classify certain mutations as "severe" or "mild", yet individuals, even siblings, with the same mutations can show dramatically different disease severities (Summers, 1996; Scriver and Waters, 1999; Dipple and McCabe, 2000).

For any genetic disease in which degradation of the mutant protein plays a pathogenic role, it might be envisaged that inter-individual differences in capacities for protein folding and assembly or for proteolysis could modulate the disease phenotype. Direct evidence on this point is currently sparse; not surprisingly, since only in a few disorders have the specific proteases and/or chaperones involved been delineated. However, the principle is clearly established by the example of PiZZ $\alpha 1$ antitrypsin deficiency. Fibroblasts from the subgroup of patients with liver pathology, associated with accumulation of misfolded $\alpha 1-A T Z$, demonstrated in culture markedly retarded degradation of the $\alpha 1-A T Z$ mutant protein compared to fibroblasts from patients without liver disease (Wu et al., 1994). This showed that genetic factors other than the primary disease locus significantly influenced ability to dispose of the mutant protein. Six years later the pathways involved in this proteolysis are still being painstakingly dissected out, indicating a complex picture involving both ubiquitin-dependent and independent proteasomal mechanisms (Teckman et al., 2000), with the individual disease-modifying component(s) yet to be identified.

Mutations in genes encoding proteases, as well as inhibitors and regulators of proteolytic pathways, have been unambiguously shown to cause numerous human diseases, both inherited and acquired (oncogenic) (Kato, 1999; Vu and Sakamoto, 2000). These disorders include complex syndromes such as Angelman and von HippelLindau, in both of which the primary defect affects a ligase which adds ubiquitin to proteins, targeting them for degradation. Functional links between the gene defects and the clinical phenotypes were by no means immediately self-evident, and the near future is likely to unearth further surprising causative relationships between mutations which disorder proteolysis and disease phenotypes. It is tempting to speculate that more subtle polymorphic variation in genes encoding proteins involved in proteolysis or protein folding will contribute to the modulation of phenotype in many monogenic disorders. Only time will tell how significant variation in these systems may or may not prove to be, in comparison with the other genetic and environmental factors which together ensure that "monogenic traits are not simple" (Scriver and W aters, 1999; Hartman et al., 2001).

\section{Prospects for Therapy: Advent of the "Designer Chaperones"}

At the beginning of the new millenium the available therapeutic options for most monogenic loss of function diseases remain severely limited (Scriver and Treacy, 1999). Gene therapy has not thus far materialised into the "cure-all" which it was once hoped by many to represent, and maturing understanding of that field has brought with it the realisation that there are many technical and biological hurdles still to overcome. Recognition that the pathogenesis of many of these diseases involves defective protein folding and assembly and increased proteolytic degradation requires us to evaluate critically the potential for artificial manipulation of these processes as a new therapeutic approach.

Inhibition of proteases is unlikely to be widely, if at all, applicable. Certainly inhibition of such major pathways as proteasomal degradation would derange a multitude of other cellular functions (Mayer, 2000). Inhibition of proteases with a very narrow substrate specificity could be considered, but with multiple provisos. The aberrantlyfolded form of the mutant protein would have to be functionally active and also not have other adverse effects on the cell (which could only be determined empirically). An apparently narrow protease substrate specificity could 
simply reflect a shortfall in current knowledge; proteases believed to have a "specific function" have a tendency to gradually reveal new substrates and thus new functions (Wang et al., 2000). Finally, for those mutant proteins which show prolonged retention in intracellular compartments during their trafficking, there is no guarantee that preventing their degradation is all that is required to secure their release. The list collectively is daunting, and encourages one instead to address the other side of the problem; namely, protein folding, assembly and stability.

A general up-regulation of broad-specificity chaperone proteins might at first sight be expected to solve the problem in many disorders. However, chaperones do not simply provide a passive buffer against misfolding and misassembly; they appear also to be actively involved in judging proteins to be unsalvageable and targeting them for degradation (Suzuki et al., 1997; Ellgard et al., 1999). The balance is a delicate one, and at higher cellular concentrations chaperones might also interact with properly folded proteins and cause their inappropriate degradation (Wickner et al., 1999); moreover, chaperones appear to actually exacerbate the formation of some proteaseresistant amyloid protein aggregates (Wickner et al., 1999), perhaps in the process of an abortive rescue attempt. Chaperones also have numerous other biological roles, such as signal transduction (Wickner et al., 1999; DeFranco, 2000). Those chaperones and other protective proteins which appear most specific in their interactions (Ellgard et al., 1999) would be the best candidates for manipulation, but again the caveat here is the possibility of hitherto unsuspected interactions involving these proteins (Leroux and Hartl, 2000).

The use of so-called "chemical chaperones" as an alternative approach to the problem of protein misfolding was proposed (Brown et al., 1997) based on a timely revisiting of some old observations. Glycerol and other low molecular weight compounds, long known to stabilise the native state of isolated proteins in vitro, could correct the effects of various mutations in yeast by "osmotic remediation" (Hawthorne and Friss, 1964). Subsequently it was shown that three main classes of such osmolytes are in fact naturally produced by various cells as a defence against protein misfolding under conditions of osmotic stress. Brown et al. (1997) showed that glycerol and trimethylamine $\mathrm{N}$-oxide (TMANO) corrected, in cultured cells, protein folding defects in mutant forms of CFTR $(\Delta \mathrm{F} 508)$, the p53 tumour suppressor protein, the viral oncogene protein $\mathrm{pp} 60^{\mathrm{src}}$ and the ubiquitin activating enzyme E1. The mechanism of effect appears complex and multi-faceted, and it involves a general alteration of the aqueous cellular environment rather than a direct interaction between the compound and the protein per se, so that the term "chaperone" in this context is something of a misnomer. Nevertheless, the effects of these chemicals, however indirect their action, evidently included a beneficial impact upon the kinetic partitioning between folding versus misfolding pathways (Brown et al., 1997). However, the effective concentrations (100-1000 mM) would probably be impossible to obtain in most tissues in vivo, and even if achieved would very likely frequently produce other major problems. TMANO was subsequently shown to correct, in cultured cells, mutant aquaporin-2 trafficking in nephrogenic diabetes insipidus, at concentrations which arguably might be achievable under physiological conditions in the relevant tissue, renal medulla (Tamarappoo and Verkman, 1998). Meanwhile the encouraging early proof-of-principle observations on the effects of "chemical chaperones" prompted a search for compounds which would be effective at lower concentration and without appreciable toxicity.

Several groups of researchers have reasoned that, in order to find a chemical which will rescue a mutant protein by acting as an artificial chaperone at low (micromolar or less) concentration, the best starting point would be to examine compounds already known to interact, directly, specifically, and with high affinity, with the wild-type protein in question. Such features may be considered functional prerequisites for any potential "designer chaperone". The human multidrug transporter (P-glycoprotein) was used as a model system to study this approach in cultured cells (Loo and Clarke, 1997). Multiple artificial missense mutations in this protein cause its misfolding, retention and degradation in the ER. Four structurally different cellpermeable compounds (two substrates and two inhibitors of drug transport) were all, at micromolar concentrations, able to rescue function for many different mutant isoforms of the protein. The normal trafficking of the protein together with its processing into a fully functional mature form was enhanced, and the rate of its degradation drastically slowed.

Application of this approach to mutations causing monogenic loss of function diseases has quickly followed. Mutations in the V2 vasopressin receptor (V2R) gene cause $\mathrm{X}$-linked nephrogenic diabetes insipidus, many by impairing protein folding such that the receptor fails to escape ER degradation and to reach the plasma membrane. Functional rescue of eight different missense mutations using two different cell-permeable V2R antagonists was observed (Morello et al., 2000; Welch and Howard, 2000). The mutant receptors were transported to the cell membrane where they could, like the wild-type, both bind vasopressin and activate adenylate cyclase to initiate signal transduction.

A second example (Fan et al., 1999) concerns mutations in the gene encoding lysosomal $\alpha$-galactosidase A ( $\alpha$-Gal A) which cause Fabry disease, a disorder of glycosphingolipid metabolism. Once again, several of these mutations have been shown to cause misfolding and abortive exit from the ER leading to the enzyme's degradation. Cell lines derived from Fabry disease patients with different mutant genotypes were treated with a potent competitive inhibitor, 1-deoxy-galactonojirimycin (DGJ) at $20 \mu \mathrm{M}$ concentration. This concentration achieves neartotal inhibition of the enzyme in vitro, but the actual intralysosomal concentration was far lower, probably due in part to $\mathrm{pH}$-induced dissociation of enzyme and inhibitor. DGJ treatment accelerated the maturation and transport of the mutant enzymes, enabling them to reach the lysosome, and enhanced the enzyme activity in lymphoblasts and fibroblasts. Also oral administration of DGJ to transgenic mice overexpressing a mutant $\alpha-G a l A$ substantially elevated the enzyme activity in several organs. 
Some generally applicable observations emerge from the exciting observations above. Heterogeneity of mutations appears less of a barrier to the development of relevant pharmacological chaperones than was previously feared (Morello et al., 2000). There are various possible suitable ligand types; antagonists and inhibitors can be useful if they can act as chaperones at sub-inhibitory concentrations or if they dissociate from a mutant protein after it has been safely escorted to a correctly assembled and stable functional conformation. Existing knowledge of the relevant biology for other proposed mutant protein targets will often guide decisions as to whether a substrate, cofactor or other ligand might be used. Loss of function recessive phenotypes represent particularly good candidates for correction by chemical chaperones (provided of course that the particular mutations involved do not directly ablate the function of the protein molecule), since the presence of even a relatively small amount of an active protein in the correct subcellular destination is often adequate to prevent the disease phenotype. Highthroughput screening for chaperone function of new compounds generated by combinatorial chemistry may contribute to the treatment of some of these genetic disorders. For others it appears that a little creative imagination, if overlaid on a solid foundation of biochemistry and cell biology, could prove both necessary and sufficient.

\section{Acknowledgements}

The author is grateful to $\mathrm{Dr}$ Charles Scriver and Dr Michael Parniak for years of encouragement and synaptic stimulation, and for reading this manuscript. Thanks to Lynne Prevost for tracking down reference articles, and to Yves Sabbagh, Dr. H.S. Tenenhouse, and Dr A. Pshezhetsky for willingly sharing data prior to their publication.

\section{References}

Agashe, V., and Hartl, F.-U. 2000. Roles of molecular chaperones in cytoplasmic protein folding. Cell Devel. Biol. 11: 15-25.

Baker, D. 2000. A surprising simplicity to protein folding. Nature 405: 39-42.

Bass, J., Turck, C., Rouard, M., and Steiner, D.F. 2000. Furin-mediated processing in the early secretory pathway: sequential cleavage and degradation of misfolded insulin receptors. Proc. Natl. Acad. Sci. USA 97: 11905-11909.

Benson, M.D. 2001. Amyloidosis. In: The Molecular and Metabolic Bases of Inherited Disease, $8^{\text {th }}$ edn. C.R. Scriver, A.L. Beaudet, D. Valle, W.S. Sly, eds. B. Childs, K.W. Kinzler, B. Vogelstein, associate eds. McGraw-Hill, New York. p. 5345-5378.

Berson, J.F., Frank, D.W., Calvo, P.A., Bieler, B.M., and Marks, M.S. 2000. A common temperature-sensitive allelic form of human tyrosinase is retained in the endoplasmic reticulum at the nonpermissive temperature. J. Biol. Chem. 275: 12281-12289.

Betts, S., Haase-Pettingell, C., and King, J. 1997. Mutational effects on inclusion body formation. Advances in Protein Chemistry 50: 243-264.
Bradford, T.M., Gething, M.-J., Davey, R., Hopwood, J.J., and Brooks, D.A. 1999. Processing of normal lysosomal and mutant $\mathrm{N}$-acetylgalactosamine 4-sulphatase: BiP (immunoglobulin heavy-chain binding protein) may interact with critical protein contact sites. Biochem. J. 341: 193-201.

Brooks, D.A. 1997. Protein processing: a role in the pathophysiology of genetic disease. FEBS Lett. 409: 115120.

Bross, P., Andresen, B.S., and Gregersen, N. 1998. Impaired folding and subunit assembly as disease mechanism: the example of medium-chain acyl-CoAdehydrogenase deficiency. Prog. Nucleic Acid Res. Mol. Biol. 58: 303-337.

Bross, P., Corydon, T.J., Andresen, B.S., Jorgensen, M.M., Bolund, L., and Gregersen, N. 1999. Protein misfolding and degradation in genetic diseases. Hum. Mutat. 14: 186-198.

Brown, C.R., Hong-Brown, L.Q., and Welch, W.J. 1997. Correcting temperature-sensitive protein folding defects. J. Clin. Invest. 99: 1432-1444.

Byers, P. 2001. Disorders of collagen biosynthesis and structure. In: The Molecular and Metabolic Bases of Inherited Disease, $8^{\text {th }}$ edn. C.R. Scriver, A.L. Beaudet, D. Valle, W.S. Sly, eds. B. Childs, K.W. Kinzler, B. Vogelstein, associate eds. McGraw-Hill, New York. p. 5241-5285.

Capecchi, M.R., Capecchi, N.E., Hughes, S.H., and Wahl, G.M. Selective degradation of abnormal proteins in mammalian tissue culture cells. 1974. Proc. Natl. Acad. Sci. USA 71: 4732-4736.

Castanie, M.-P., Berges, H., Oreglia, J., Prere, M.-F., and Fayet, O. 1997. A set of pBR322-compatible plasmids allowing the testing of chaperone-assisted folding of proteins overexpressed in Escherichia coli. Anal. Biochem. 254: 150-152.

Corydon, T.J., Bross, P., Jensen, T.G., Corydon, M.J., Lund, T.B., Jensen, U.B., Kim, J.-J.P., Gregersen, N., and Bolund, L. 1998. Rapid degradation of short chain acylcoA dehydrogenase variants with temperature-sensitive folding defects occurs after import into mitochondria. J. Biol. Chem. 273: 13065-13071.

DeFranco, D.B. 2000. Role of molecular chaperones in subcellular trafficking of glucocorticoid receptors. Kidney Int. 57: 1241-1249.

Diamant, S., Ben-Zvi, A.P., Bukau, B., and Goloubinoff, P. 2000. Size-dependent disaggregation of stable protein aggregates by the DnaK chaperone machinery. J. Biol. Chem. 275: 21107-21113.

Dietz, H.C., and Pyeritz, R.E. 2001. Marfan Syndrome and related disorders. In: The Molecular and Metabolic Bases of Inherited Disease, $8^{\text {th }}$ edn. C.R. Scriver, A.L. Beaudet, D. Valle, W.S. Sly, eds. B. Childs, K.W. Kinzler, B. Vogelstein, associate eds. McGraw-Hill, New York. p. 5287-5311.

Dinner, A.R., Sali, A., Smith, L.J., Dobson, C.M., and Karplus, M. 2000. Understanding protein folding via freeenergy surfaces from theory and experiment. Trends Biochem. Sci. 25: 331-339.

Dipple, K.M., and McCabe, E.R.B. 2000. Phenotypes of patients with "simple" Mendelian disorders are complex 
traits: thresholds, modifiers, and systems dynamics. Am. J. Hum. Genet. 66: 1729-1735.

Ellgard, L., Molinari, M., and Helenius, A. 1999. Setting the standards: quality control in the secretory pathway. Science 286: 1882-1888.

Fan, J.-Q., Ishii, S., Asano, N., and Suzuki, Y. 1999. Accelerated transport and maturation of lysosomal $\alpha$ galactosidase $A$ in Fabry lymphoblasts by an enzyme inhibitor. Nature Med. 5: 112-115.

Fayadat, L., Siffroi-Fernandez, S., Lanet, J., and Franc, J.-L. 2000. Degradation of human thyroperoxidase in the endoplasmic reticulum involves two different pathways depending on the folding state of the protein. J. Biol. Chem. 275: 15948-15954.

Gamez, A., Perez, B., Ugarte, M., and Desviat, L.R. 2000. Expression analysis of phenylketonuria mutations. Effect on folding and stability of the phenylalanine hydroxylase protein. J. Biol. Chem. 275: 29737-29742.

Geier, E., Pfeifer, G., Wilm, M., Lucchiari-Hartz, M., Baumeister, W., Eichmann, K., and Niedermann, G. 1999. A giant protease with potential to substitute for some functions of the proteasome. Science 283: 978-981.

Gregersen, N., Bross, P., Jorgensen, M.M., Corydon, T.J., and Andresen, B.S. 2000. Defective folding and rapid degradation of mutant proteins is a common disease mechanism in genetic disorders. (Transcript of presentation to the annual symposium of the Society for the Study of Inborn Errors of Metabolism, September 1999) J. Inher. Metab. Dis. 23: 441-447.

Hartman, J.L., Garvik, B., and Hartwell, L. 2001. Principles for the buffering of genetic variation. Science 291: 10011004.

Hawkes, R., Grutter, M.G., and Schellman. 1984. Thermodynamic stability and point mutations of bacteriophage T4 lysozyme. J. Mol. Biol. 175: 195-212.

Hawthorne, D.C., and Friss, J. 1964. Osmotic remedial mutants: A new classification for nutritional mutants in yeast. Genetics 50: 829-839.

Jorgensen, M.M., Jensen, O.N., Holst, H.U., Hansen, J.J., Corydon, T.J., Bross, P., Bolund, L., and Gregersen, N. 2000. Grp78 is involved in retention of mutant low density lipoprotein receptor protein in the endoplasmic reticulum. J. Biol. Chem. 275: 33861-33868.

Kato, G.J. 1999. Human genetic diseases of proteolysis. Hum. Mutat. 13: 87-98.

Kopito, R.R. 2000. Aggresomes, inclusion bodies and protein aggregation. Trends Cell Biol. 10: 524-530.

Kopito, R.R., and Sitia, R. 2000. Aggresomes and Russell bodies: symptoms of cellular indigestion? EMBO Reports 1: 225-231.

Krawczak, M., Ball, E.V., Fenton, I., Stenson, P.D., Abeysinghe, S., Thomas, N., and Cooper, D.N. 2000. Human Gene Mutation Database - a biomedical information and research resource. Hum. Mutat. 15: 4551.

Kuznetsov, G., and Nigam, S.K. 1998. Folding of secretory and membrane proteins. N. Engl. J. Med. 339: 1688-1695.

Lai, K., Langley, S.D., Dembure, P.P., Hjelm L.N., and Elsas L.J. II. 1998. Duarte allele impairs biostability of galactose1-phosphate uridyltransferase in human lymphoblasts. Hum. Mutat. 11: 28-38.
Leroux, M.R., and Hartl, F.-U. 2000. Protein folding: versatility of the cytosolic chaperonin TRIC/CCT. Curr. Biol. 10: R260-264.

Loo, T.W., and Clarke, D.M. 1997. Correction of defective protein kinesis of human P-glycoprotein mutants by substrates and modulators. J. Biol. Chem. 272: 709-712.

Lukong, K.E., Landry, K. Elsliger, M.-A., Chang, Y., Lefrancois, S., Morales, C.R., and Pshezhetsky, A.V. 2001. Mutations in sialidosis impair sialidase binding to the lysosomal multienzyme complex. J. Biol. Chem., in press.

Mayer, R.J. The meteoric rise of regulated intracellular proteolysis. 2000. Nature Rev. 1: 145-148.

Morello, J.-P., Salahpour, A., Laperriere, A., Bernier, V., Arthus, M.-F., Lonergan, M., Petaja-Repo, U., Angers, S., Morin, D., Bichet, D.G., and Bouvier, M. 2000. Pharmacological chaperones rescue cell-surface expression and function of misfolded V2 vasopressin receptor mutants. J. Clin. Invest. 105: 887-895.

Netzer, W.J., and Hartl, F.U. 1998. Protein folding in the cytosol: chaperonin-dependent and- independent mechanisms. Trends Biochem. Sci. 23: 68-73.

Scriver, C.R., and Treacy, E.P. 1999. Is there treatment for "genetic" disease? Molec. Genet. Metab. 68: 93-102.

Scriver, C.R., and Waters, P.J. 1999. Monogenic traits are not simple: lessons from phenylketonuria. Trends Genet. 15: 267-272.

Summers, K.M. 1996. Relationship between genotype and phenotype in monogenic diseases: relevance to polygenic diseases. Hum. Mutat. 7: 283-293.

Suzuki, C.K., Rep, M., van Dijl, J.M., Suda, K. Grivell, L.A., and Schatz, G. 1997. ATP-dependent proteases that also chaperone protein biogenesis. Trends Biochem. Sci. 22: 118-123.

Tamarappoo, B.K., and Verkman, A.S. 1998. Defective aquaporin-2 trafficking in nephrogenic diabetes insipidus and correction by chemical chaperones. J. Clin. Invest. 101: 2257-2267.

Tamarappoo, B.K., Yang, B., and Verkman, A.S. 1999. Misfolding of mutant aquaporin-2 water channels in nephrogenic diabetes insipidus. J. Biol. Chem. 274: 24825-24831.

Teckman, J.H., Gilmore, R., and Perlmutter, D.H. 2000. Role of ubiquitin in proteasomal degradation of mutant alpha(1)-antitrypsin Z in the endoplasmic reticulum. Am. J. Physiol. Gastrointest. Liver Physiol. 278: G39-48.

Turner, G.C., and Varshavsky, A. 2000. Detecting and measuring cotranslational protein degradation in vivo. Science 289: 2117-2120.

Tyedmers, J., Kruse, M., Lerner, M., Demand, J., Hohfeld, J., Solsbacher, J., Volkmer, J.R., and Zimmermann, R. 2000. Assembly of heterodimeric luciferase after de novo synthesis of subunits in rabbit reticulocyte lysate involves $\mathrm{Hsc70}$ and Hsp40 at a post-translational stage. Eur. J. Biochem. 267: 3575-3582.

Vinogradova, M.V., Michaud, L., Mezentev, A.V., Lukong, K.E., El-Alfy, M., Morales, C.R., Potier, M., and Pshezhetsky, A.V. 1998. Molecular mechanism of lysosomal sialidase deficiency in galactosialidosis involves its rapid degradation. Biochem. J. 330: 641-650. Vu, P.K., and Sakamoto, K.M. 2000. Ubiquitin-mediated 
proteolysis and human disease. Molec. Genet. Metab. 71: 261-266.

Wagenknecht, B., Hemisson, M., Grosarth, P., Liston, P., Krammer, P.H., and Weller, M. 2000. Proteasome inhibitor-induced apoptosis of glioma cells involves the processing of multiple caspases and cytochrome $c$ release. J. Neurochem. 75: 2288-2297.

Wang, E.W., Kessler, B.M., Borodovsky, A., Cravatt, B.F., Boggio, M., Ploegh, H., and Glas, R. 2000. Integration of the ubiquitin-proteasome pathway with a cytosolic oligopeptidase activity. Proc. Natl. Acad. Sci. USA. 99909995.

Wanker, E.E. 2000. Protein aggregation in Huntington's and Parkinson's disease: implications for therapy. Molec. Med. Today 6: 387-391.

Ward, C.L., and Kopito, R.R. 1994. Intracellular turnover of cystic fibrosis transmembrane conductance regulator. Inefficient processing and rapid degradation of wild-type and mutant proteins. J. Biol. Chem. 269: 25710-25718.

Waters, P.J., Parniak, M.A., Akerman, B.R., and Scriver, C.R. 2000. Characterization of phenylketonuria missense substitutions, distant from the phenylalanine hydroxylase active site, illustrates a paradigm for mechanism and potential modulation of phenotype. Molec. Genet. Metab. 69:101-110.

Welch, W.J., and Howard, M. 2000. Antagonists to the rescue. J. Clin. Invest. 105: 853-854.

Wickner, S., Maurizi, M.R., and Gottesman, S. 1999. Posttranslational Quality Control: folding, refolding, and degrading proteins. Science 286: 1888-1893.

Wu, Y., Whitman, I., Molmenti, E., Moore, K., Hippenmeyer, P., and Perlmutter, D.H. 1994. A lag in intracellular degradation of mutant $\alpha 1$-antitrypsin correlates with the liver disease phenotype in homozygous PiZZ a1antitrypsin deficiency. Proc. Natl. Acad. Sci. USA 91: 90149018. 


\section{Further Reading}

Caister Academic Press is a leading academic publisher of advanced texts in microbiology, molecular biology and medical research. Full details of all our publications at caister.com

- MALDI-TOF Mass Spectrometry in Microbiology Edited by: M Kostrzewa, S Schubert (2016) www.caister.com/malditof

- Aspergillus and Penicillium in the Post-genomic Era Edited by: RP Vries, IB Gelber, MR Andersen (2016) www.caister.com/aspergillus2

- The Bacteriocins: Current Knowledge and Future Prospects Edited by: RL Dorit, SM Roy, MA Riley (2016)

www.caister.com/bacteriocins

- Omics in Plant Disease Resistance Edited by: V Bhadauria (2016) www.caister.com/opd

- Acidophiles: Life in Extremely Acidic Environments Edited by: R Quatrini, DB Johnson (2016) www.caister.com/acidophiles

- Climate Change and Microbial Ecology: Current Research and Future Trend

Edited by: J Marxsen (2016)

www.caister.com/climate

- Biofilms in Bioremediation: Current Research and Emerging Technologies

Edited by: G Lear (2016)

www.caister.com/biorem

- Microalgae: Current Research and Applications Edited by: MN Tsaloglou (2016) www.caister.com/microalgae

- Gas Plasma Sterilization in Microbiology: Theory, Applications, Pitfalls and New Perspectives Edited by: H Shintani, A Sakudo (2016) www.caister.com/gasplasma

- Virus Evolution: Current Research and Future Directions Edited by: SC Weaver, M Denison, M Roossinck, et al. (2016) www.caister.com/virusevol

- Arboviruses: Molecular Biology, Evolution and Control Edited by: N Vasilakis, DJ Gubler (2016) www.caister.com/arbo

- Shigella: Molecular and Cellular Biology Edited by: WD Picking, WL Picking (2016) www.caister.com/shigella

-Aquatic Biofilms: Ecology, Water Quality and Wastewater Treatment

Edited by: AM Romaní, H Guasch, MD Balaguer (2016)

www.caister.com/aquaticbiofilms

- Alphaviruses: Current Biology

Edited by: S Mahalingam, L Herrero, B Herring (2016)

www.caister.com/alpha

- Thermophilic Microorganisms

Edited by: F Li (2015)

www.caister.com/thermophile
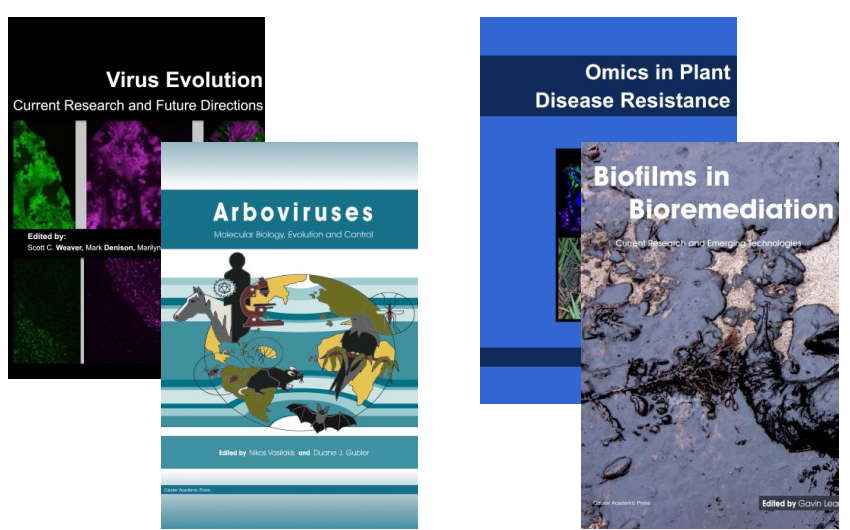
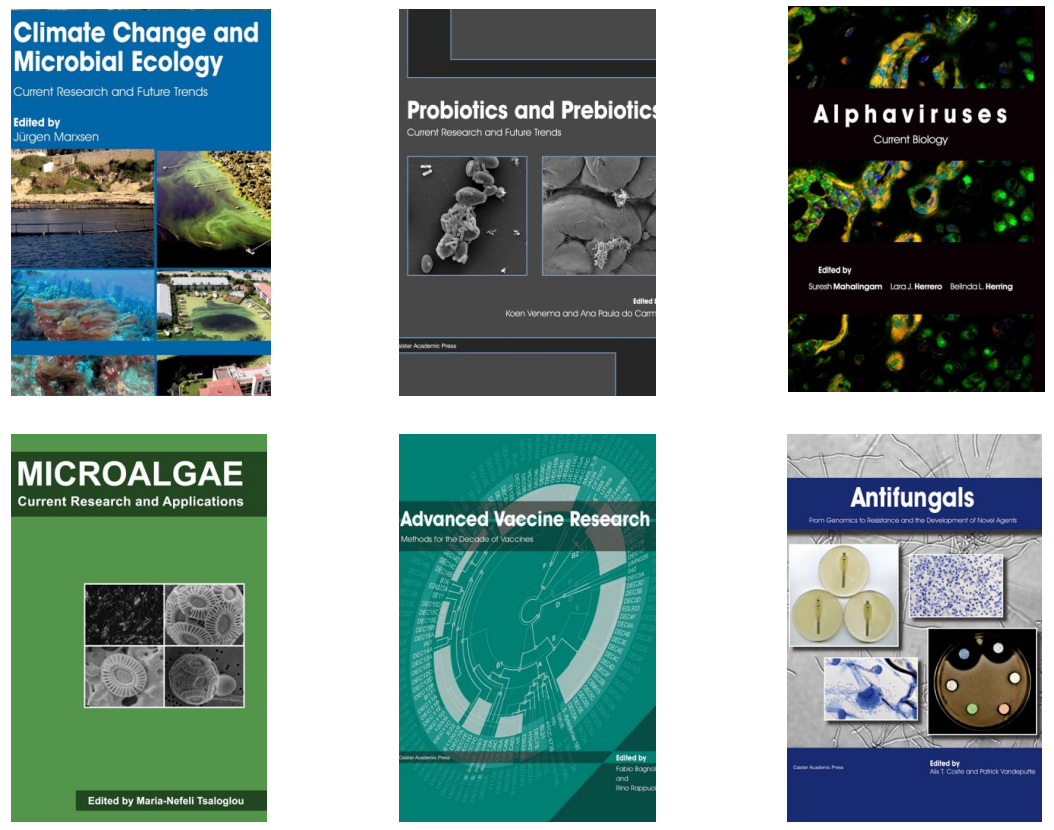

- Flow Cytometry in Microbiology: Technology and Applications Edited by: MG Wilkinson (2015) www.caister.com/flow

- Probiotics and Prebiotics: Current Research and Future Trends Edited by: K Venema, AP Carmo (2015) www.caister.com/probiotics

- Epigenetics: Current Research and Emerging Trends Edited by: BP Chadwick (2015) www.caister.com/epigenetics2015

- Corynebacterium glutamicum: From Systems Biology to Biotechnological Applications

Edited by: A Burkovski (2015)

www.caister.com/cory2

- Advanced Vaccine Research Methods for the Decade of Vaccines

Edited by: F Bagnoli, R Rappuoli (2015)

www.caister.com/vaccines

- Antifungals: From Genomics to Resistance and the Development of Novel Agents

Edited by: AT Coste, P Vandeputte (2015)

www.caister.com/antifungals

- Bacteria-Plant Interactions: Advanced Research and Future Trends Edited by: J Murillo, BA Vinatzer, RW Jackson, et al. (2015) www.caister.com/bacteria-plant

\section{- Aeromonas}

Edited by: J Graf (2015)

www.caister.com/aeromonas

- Antibiotics: Current Innovations and Future Trends

Edited by: S Sánchez, AL Demain (2015)

www.caister.com/antibiotics

- Leishmania: Current Biology and Contro Edited by: S Adak, R Datta (2015) www.caister.com/leish2

- Acanthamoeba: Biology and Pathogenesis (2nd edition) Author: NA Khan (2015)

www.caister.com/acanthamoeba2

- Microarrays: Current Technology, Innovations and Applications Edited by: Z He (2014)

www.caister.com/microarrays2

- Metagenomics of the Microbial Nitrogen Cycle: Theory, Methods and Applications

Edited by: D Marco (2014)

www.caister.com/n2 